\title{
Moisture dry-out from steel faced insulated sandwich panels
}

\author{
Kristo Kalbe ${ }^{1 *}$, Hubert Piikov ${ }^{1}$, Jyrki Kesti ${ }^{2}$, Erkki Honkakoski ${ }^{2}$, Jarek Kurnitski ${ }^{1}$, Targo Kalamees ${ }^{3,1}$ \\ ${ }^{1}$ Tallinn University of Technology, nZEB Research Group, Tallinn, Estonia \\ ${ }^{2}$ Ruukki Construction Oy (SSAB), Hämeenlinna, Finland \\ ${ }^{3}$ Smart City Center of Excellence (Finest Twins), Tallinn University of Technology, Ehitajate tee 5, Tallinn, Estonia
}

\begin{abstract}
This study analyses moisture dry-out from a steel faced insulated sandwich panel. Three test walls, with lower parts close to the free water level, were studied in a laboratory under different climatic conditions to measure their dry-out capacity and to obtain data for simulation model calibration. The hygrothermal simulations were done with the simulation tool Delphin in stable climatic conditions to determine the magnitude of the moisture dry-out capacity. Comparison of the measured and simulated relative humidity showed sufficiently good agreement. The results indicate that panels of this type have some dry-out capacity under summer and spring climatic conditions (about 2-3 g/day at best) but during autumn and winter their dry-out capacity is limited. In case of a water leakage (e.g. due to rain during the installation of the panels), the moisture dry-out is negligible. To minimise the wetting of insulation, weather protection during construction and during storage is necessary.
\end{abstract}

\section{Introduction}

The use of prefabricated building elements increases construction efficiency [1], reduces construction waste [2] and could reduce greenhouse gas emissions [3]. Lu found that using steel faced sandwich panel assemblies is one of the most optimal levels of prefabrication, especially for urban high density construction sites [4]. In addition to the construction of new buildings the use of two-dimensional prefabricated panels has also gained popularity in the renovation of buildings [5,6] and marine applications [7]. Steel faced sandwich panels, filled with polyurethane or mineral wool, are widely used in warehouses, industrial and commercial buildings. The yearly installed area of these panels amounts up to 130 million $\mathrm{m}^{2}$ in Europe [8].

Based on the Construction Products Regulation [9], buildings must be designed and constructed so as not to endanger human health as a result of high humidity. The steel faced insulated sandwich panel is quite moisture resistant as it is covered with a water and vapour tight surface (steel). When joints of the panels are tight, the building envelope is tolerant to moisture movement by diffusion and convection as well as to free water flow. However, if water can penetrate into the insulation space, the dry-out period could be very long, causing moisture related problems to the panel itself. Previous research has shown that the drying out of moisture could significantly influence the overall hygrothermal performance of the building envelope [10-13].

This study analyses the moisture dry-out from a steel faced insulated sandwich panel by applying laboratory measurements and hygrothermal modelling. The moisture dry-out is also studied for different tapes used for covering the joints of the panels in wall assemblies.

\section{Methods}

\subsection{Laboratory measurements}

A series of tests were conducted in the TalTech nZEB test facility to study the water vapour distribution and moisture dry-out speed in the steel faced insulated sandwich panel. The indoor temperature and humidity of the test facility can be controlled as necessary. Measured data from the tests was also used for calibrating hygrothermal models. Three test walls (TW) were cut from sandwich panels used in a previous study conducted in HAMK Tech in Finland [14]. See Fig. 1 for a descriptive drawing of the TW.

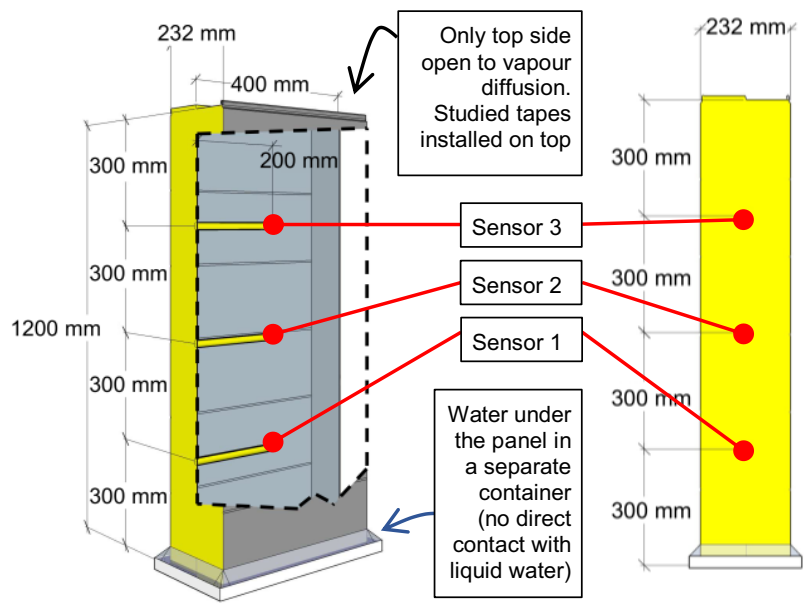

Fig. 1. A 3D and a 2D section cut of a test wall with sensor locations indicated.

\footnotetext{
* Corresponding author: kristo.kalbe@taltech.ee
} 
Both TW1 and TW2 were cut in a manner that the longer sides are parallel to the insulation fibres and TW3 was cut so that the longer sides are perpendicular to the insulation fibres. The sides (full measurement period) and top (limited periods) of the TWs were covered with a selfadhesive tape with an aluminium foil surface (Flashband - Soudal Butyband Flashing Tape $10 \mathrm{~m} \times 300 \mathrm{~mm}$ ) to prevent vapour diffusion through the sides. Stainless steel water containers were placed under the TWs and filled with $1500 \mathrm{~g}$ of water for each TW to study the water vapour pressure distribution in the panel (mimicking a scenario where water has accumulated under the panels, e.g. in a plinth rail). Liquid water did not come into direct contact with the TWs. The bottom of the wall was open towards the water (via $\sim 10 \mathrm{~mm}$ of air). The connection of the water container and TW was sealed with an aluminium tape.

An array of temperature and relative humidity sensors with data loggers (HOBO UX100-023) measured the water vapour pressure distribution. Three sensors were installed on the centre line of the panel at equal distances from each other (Fig. 1). The sensors were installed from the sides of the panel and the sensor cable openings were sealed to minimise external influences on the measurements.

To study the moisture dry-out through a vapour permeable $\left(S_{\mathrm{d}}\right.$ or equivalent air layer thickness $\left.=0.05 \mathrm{~m}\right)$ and a vapour retarding $\left(S_{\mathrm{d}}=15 \mathrm{~m}\right)$ tape, a $30 \mathrm{~mm} \times 375$ $\mathrm{mm}$ aperture was covered with a tape on the top side of each TW and everything else was sealed vapour tight. The photo in Fig. 2 shows TWs during the installation of tapes on their top surfaces.

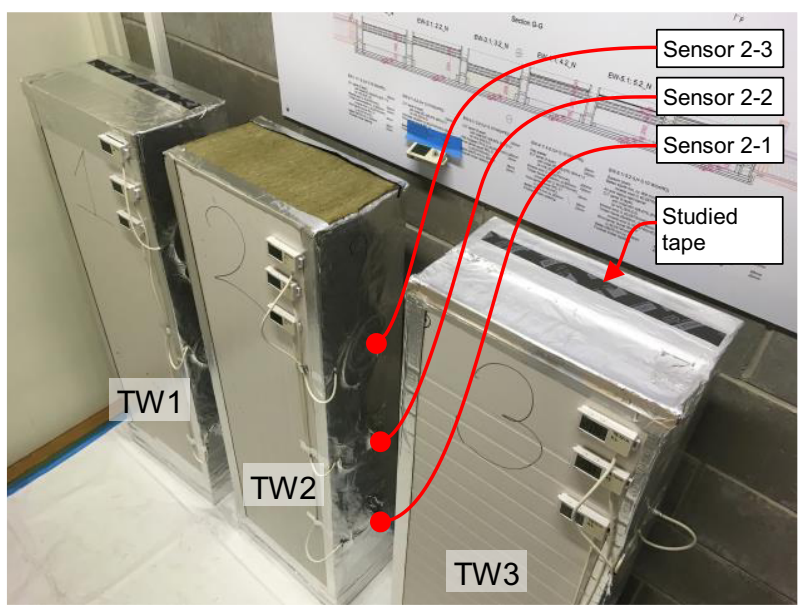

Fig. 2. Test walls during the test. Top surfaces of TW1 and TW3 are covered with sealing foil and vapour permeable tape. TW2 is fully open to diffusion on the top side (tape not yet installed).

Most of the tests were conducted in isothermal conditions $\left(t \approx 22-24{ }^{\circ} \mathrm{C}\right)$ in a test room with relative air humidity $(\mathrm{RH}) \approx 30-50 \%$ (Fig. 3 ). This resulted in a water vapour pressure between 793 and $1266 \mathrm{~Pa}$ around the TWs. The water vapour pressure near the water container under the TWs was 2642-3166 Pa. During a two-and-ahalf-week period the test specimens were also in outdoor conditions to observe the influence of rapid temperature changes. The general plan of the test is presented in Table 1.

Table 1. Numerical values for the boundary conditions in the first phase of the test.

\begin{tabular}{|c|c|c|c|c|c|}
\hline $\begin{array}{c}\text { Test } \\
\text { no. }\end{array}$ & Description & Time, days & $\begin{array}{c}t_{\mathrm{i}},{ }^{\circ} \mathrm{C} \\
\text { (test room) }\end{array}$ & \begin{tabular}{|c|}
$R H_{\mathrm{i}}, \%$ \\
(test room)
\end{tabular} & Comments \\
\hline \multirow{2}{*}{1} & Sandwich panels stored in test facility & 35 & $23-26$ & $30-50$ & \\
\hline & Preparation of TWs. Stabilisation in dry conditions & 15 & $23-26$ & $30-50$ & \\
\hline 2 & $\begin{array}{l}\text { Water containers installed under TWs. } \\
\text { Stabilisation and measuring of saturation speed } \\
\text { (TW1) and moisture dry-out and water vapour } \\
\text { permeability of mineral wool through fully open } \\
\text { top surface (TW2 \& TW3) }\end{array}$ & $\begin{array}{c}26 \\
\text { TW1 \& TW3 } \\
32 \\
\text { TW2 } \\
\end{array}$ & $22-24$ & $31-34$ & $\begin{array}{l}\text { TW 1: Fully sealed } \\
\text { TW 2: Fully open top surface } \\
\text { TW 3: Fully open top surface }\end{array}$ \\
\hline 3 & $\begin{array}{l}\begin{array}{l}\text { Water under TWs, tapes installed over TW top } \\
\text { surface aperture }(30 \mathrm{~mm} \times 375 \mathrm{~mm})\end{array} \\
\begin{array}{l}\text { Measuring moisture dry-out through aperture } \\
\text { with tapes }\end{array} \\
\end{array}$ & $\begin{array}{c}16 \\
\text { TW1 \& TW3 } \\
21 \\
\text { TW2 } \\
\end{array}$ & $22-24$ & $31-34$ & $\begin{array}{l}\text { TW 1: Tape } S_{\mathrm{d}}=0.05 \mathrm{~m} \\
\text { TW 2: Tape } S_{\mathrm{d}}=15 \mathrm{~m} \\
\text { TW 3: Tape } S_{\mathrm{d}}=0.05 \mathrm{~m}\end{array}$ \\
\hline 4 & $\begin{array}{l}\text { Water under TWs, some tapes removed } \\
\text { Measuring moisture dry-out through aperture } \\
\text { without tapes on TW1 \& TW3 }\end{array}$ & $\begin{array}{c}11 \\
\text { TW1 \& TW3 } \\
0 \\
\text { TW2 }\end{array}$ & $22-24$ & $31-34$ & $\begin{array}{l}\text { TW 1: No tape } \\
\text { TW 2: Tape } S_{\mathrm{d}}=15 \mathrm{~m} \text { still on } \\
\text { TW 3: No tape }\end{array}$ \\
\hline 5 & $\begin{array}{l}\text { Water under TWs, all tapes removed } \\
\text { Measuring moisture dry-out through aperture } \\
\text { without tapes on all TWs and with higher } \\
\text { temperature }\end{array}$ & 17 & 31-35 & 25 & $\begin{array}{l}\text { TW 1: No tape } \\
\text { TW 2: No tape } \\
\text { TW 3: No tape }\end{array}$ \\
\hline 6 & $\begin{array}{l}\text { Water under TWs, top aperture without tapes and } \\
\text { test walls placed outdoors. } \\
\text { Studying temperature variation effects and } \\
\text { measuring moisture dry-out through aperture } \\
\text { without tapes on all TWs in outdoor climate }\end{array}$ & 18 & 0-10 & & $\begin{array}{l}\text { TW 1: No tape } \\
\text { TW 2: No tape } \\
\text { TW 3: No tape } \\
\text { Outdoor RH near saturation level }\end{array}$ \\
\hline
\end{tabular}




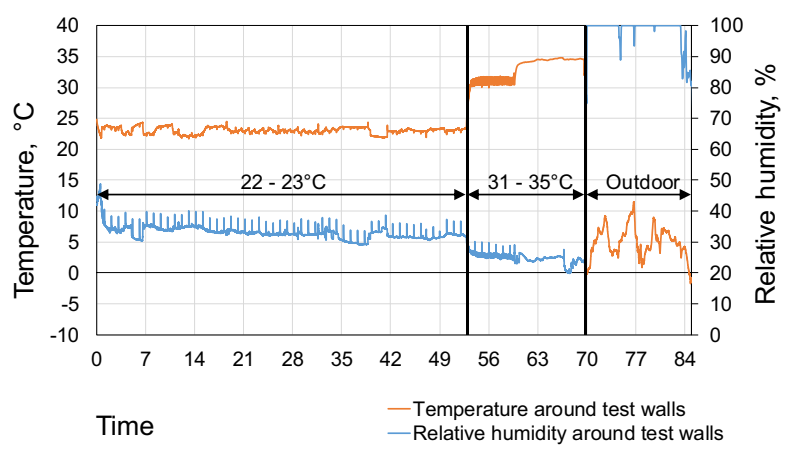

Fig. 3. Temperature and relative humidity during the tests around all sides of the TWs.

\subsection{Simulations}

The hygrothermal simulations were performed with the simulation tool Delphin [15]. The software is validated $[16,17]$ and it models coupled heat, air and moisture transport. It uses the numerical solution that is done by semi-discretisation in space (by using a finite/control volume method) and subsequent integration in time. Modelling comprises the description of fluxes in the calculation domain or in the field (between volume panels including material interfaces) and at the boundary (between volume panels and exterior or interior rooms) by physical models. Models for storage processes such as adsorption, desorption and release are also included but hysteresis is excluded. The material properties used in the simulations are given in Table 2 and in Fig. 4. Delphin's default functions of material properties that depend on the hygric environment were also included. Steel was modelled as an infinitely vapour tight surface on mineral wool.

Table 2 Material properties of mineral wool used in the modelling of the hygrothermal performance of the sandwich panel.

\begin{tabular}{l|c}
\hline $\begin{array}{l}\text { Material property } \\
\text { (base value in dry conditions) }\end{array}$ & $\begin{array}{c}\text { Mineral } \\
\text { wool }\end{array}$ \\
\hline Bulk density $\rho, \mathrm{kg} / \mathrm{m}^{3}$ & 85 \\
Thermal conductivity $\lambda, \mathrm{W} /(\mathrm{m} \cdot \mathrm{K})$ & 0.04 \\
Specific heat capacity $c, \mathrm{~J} / \mathrm{kg} \cdot \mathrm{K})$ & 840 \\
Water vapour diffusion $\mathrm{resistance}$ factor $\mu,-$ & 1.0 \\
Effective saturation $\theta, \mathrm{m}^{3} / \mathrm{m}^{3}$ & 0.9 \\
Porosity $\theta, \mathrm{m}^{3} / \mathrm{m}^{3}$ & 0.97 \\
Water uptake coefficient $A_{w}, \mathrm{~kg} /\left(\mathrm{m} \cdot \mathrm{s}^{1} / 2\right)$ & 0 \\
Liquid water conductivity $\mathrm{kl}, \mathrm{kg} /(\mathrm{m} \cdot \mathrm{s} \cdot \mathrm{Pa})$ & 0 \\
\hline
\end{tabular}

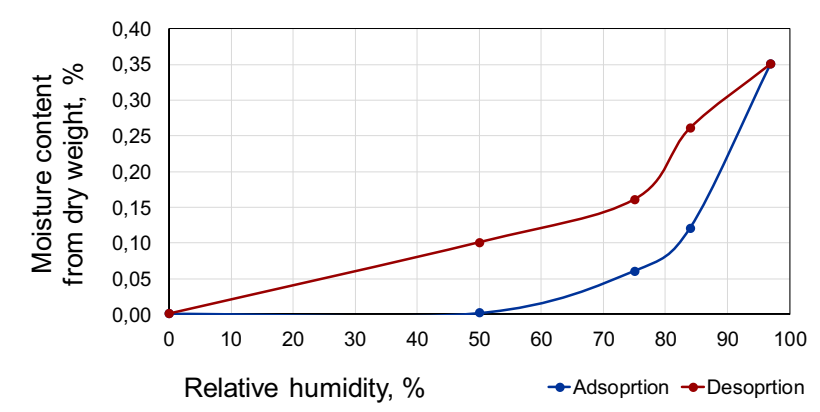

Fig. 4. Adsorption and desorption isotherms of mineral wool.
The hygrothermal models were first calibrated to match the measurements done in the laboratory. The measured environmental conditions (Fig. 3) around the TW were used as climate data in the simulations. On the bottom boundary the RH was set to $100 \%$ and no moisture transport was assumed on the sides, leaving only the top surface exposed to moisture exchange.

To study the dry-out capacity of a typical steel faced sandwich panel wall, the simulation models were updated to represent a typical structure where the panels are $6 \mathrm{~m}$ long, $3 \mathrm{~m}$ high and have a $30 \mathrm{~mm}$ vertical connecting joint. The boundary condition on one of the longer sides was simulated as outdoor climate and on the other side as indoor climate. Shorter sides were simulated as adiabatic. For the outdoor climate of these simulations, the Finnish moisture reference year, known as Jokioinen 2004, was used. Jokioinen 2004 is a critical outdoor climate (Table 3) if the internal part of the structure is protected from rain. When using Jokioinen 2004, the key influence comes from the relative humidity of the outside air, whereas the driving rain and solar radiation have a minor effect $[18,19]$. The model of the dependence of indoor temperature on the daily average outdoor temperature was used (Fig. 5). This model represents typical conditions in heated warehouses. Figure 6 shows a section cut of a steel faced sandwich panel wall assembly with a connecting joint and an excerpt of the simulation model.

Table 3 Monthly and seasonal average climatic conditions from Jokioinen 2004.

\begin{tabular}{|c|c|c|c|c|}
\hline Month & \multicolumn{2}{|c|}{ Temperature, ${ }^{\circ} \mathrm{C}$} & \multicolumn{2}{|c|}{ Relative humidity, $\%$} \\
\hline January & -7.5 & \multirow{2}{*}{-4.4} & 92 & \multirow{2}{*}{93} \\
\hline February & -5.0 & & 90 & \\
\hline March & -1.8 & \multirow{3}{*}{4.3} & 85 & \multirow{3}{*}{70} \\
\hline April & 4.9 & & 60 & \\
\hline May & 9.6 & & 64 & \\
\hline June & 12.2 & \multirow{3}{*}{14.5} & 68 & \multirow{3}{*}{75} \\
\hline July & 15.5 & & 78 & \\
\hline August & 15.7 & & 79 & \\
\hline September & 11.5 & \multirow{3}{*}{5.2} & 88 & \multirow{3}{*}{91} \\
\hline October & 4.8 & & 90 & \\
\hline November & -0.7 & & 94 & \\
\hline December & -0.8 & -4.4 & 98 & 93 \\
\hline
\end{tabular}

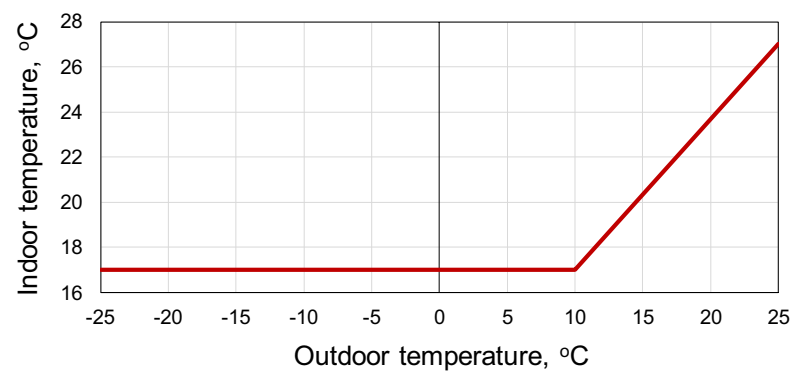

Fig. 5. Dependence of indoor temperature on outdoor temperature. 


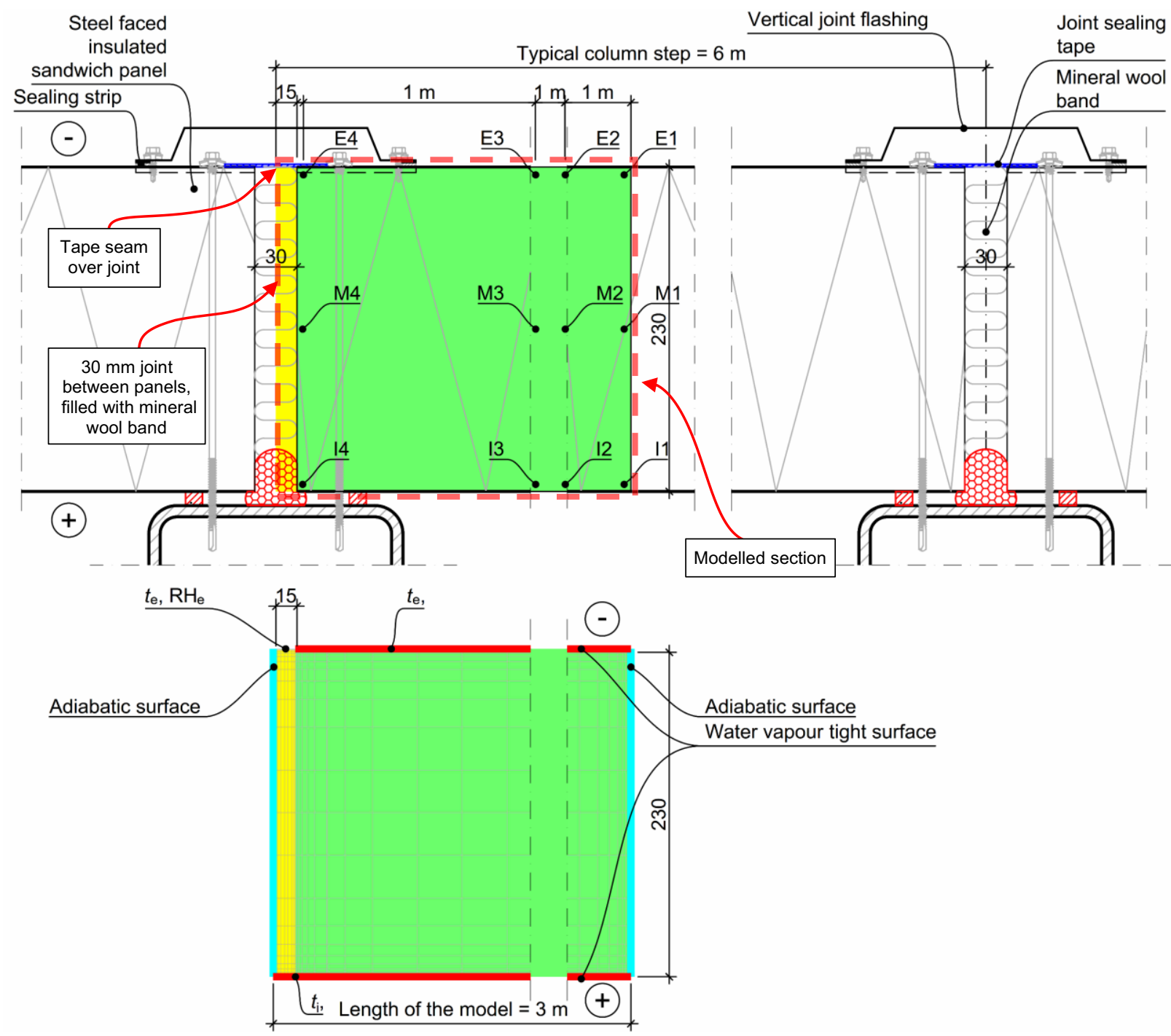

Fig. 6. Horizontal section of a typical external wall constructed with steel faced insulated sandwich panels (above) and the simulation model (below).

\section{Results and discussion}

\subsection{Calibration of the simulation model}

As the dry-out occurs horizontally from the middle of the panel towards the joint and the relative humidity equalises quickly, it is possible to model the $3 \mathrm{D}$ problem in a $2 \mathrm{D}$ model because heat influences the wall from all sides. The 1D model (heat flow only through the top and bottom sides of the TW) gave the correct temperature level but wrong dynamics (simulation showed too large inertia compared to measurements).

The water vapour pressure inside the wall was influenced by water vapour from the water container below the TW (RH 100\%) and room air humidity from the top surface $(\mathrm{RH} \approx 30-50 \%)$. Comparison of the measured and simulated water vapour pressures showed good agreement (Fig. 7, left). On day 24 the fully sealed top surface of TW1 was opened to diffusion through the $S_{\mathrm{d}}=0.05 \mathrm{~m}$ tape and the fully opened top surface of TW3 was covered with aluminium foil and a strip of $S_{\mathrm{d}}=0.05 \mathrm{~m}$ tape. The hysteresis of water vapour pressure is seen after this event (between days 24 and 41) on TW1 and TW3. Measurements from TW1 (drying) showed higher humidity than simulated during the hysteresis. Measurements from TW3 (moistening) showed good agreement with simulations as the adsorption isotherm was used in the simulations. Although the measured and simulated drying processes are in good agreement, there is a possibility of slight overestimation of drying when using the adsorption isotherm.

Comparison of the measured and simulated relative humidity showed sufficiently good agreement (Fig. 7, right), although the simulation tended to underestimate $\mathrm{RH}$ in the high humidity region.

\subsection{Dry-out capacity}

The simulations were done with constant climatic conditions derived from the seasonal averages of the selected climate data (Table 3 highlighted columns for outdoor climate; Fig. 5 for indoor temperature). Use of constant climatic conditions allowed us to describe the dry-out capability in the most or least favourable conditions. The use of constant climate conditions also helps to study the effect of climate on the drying process 

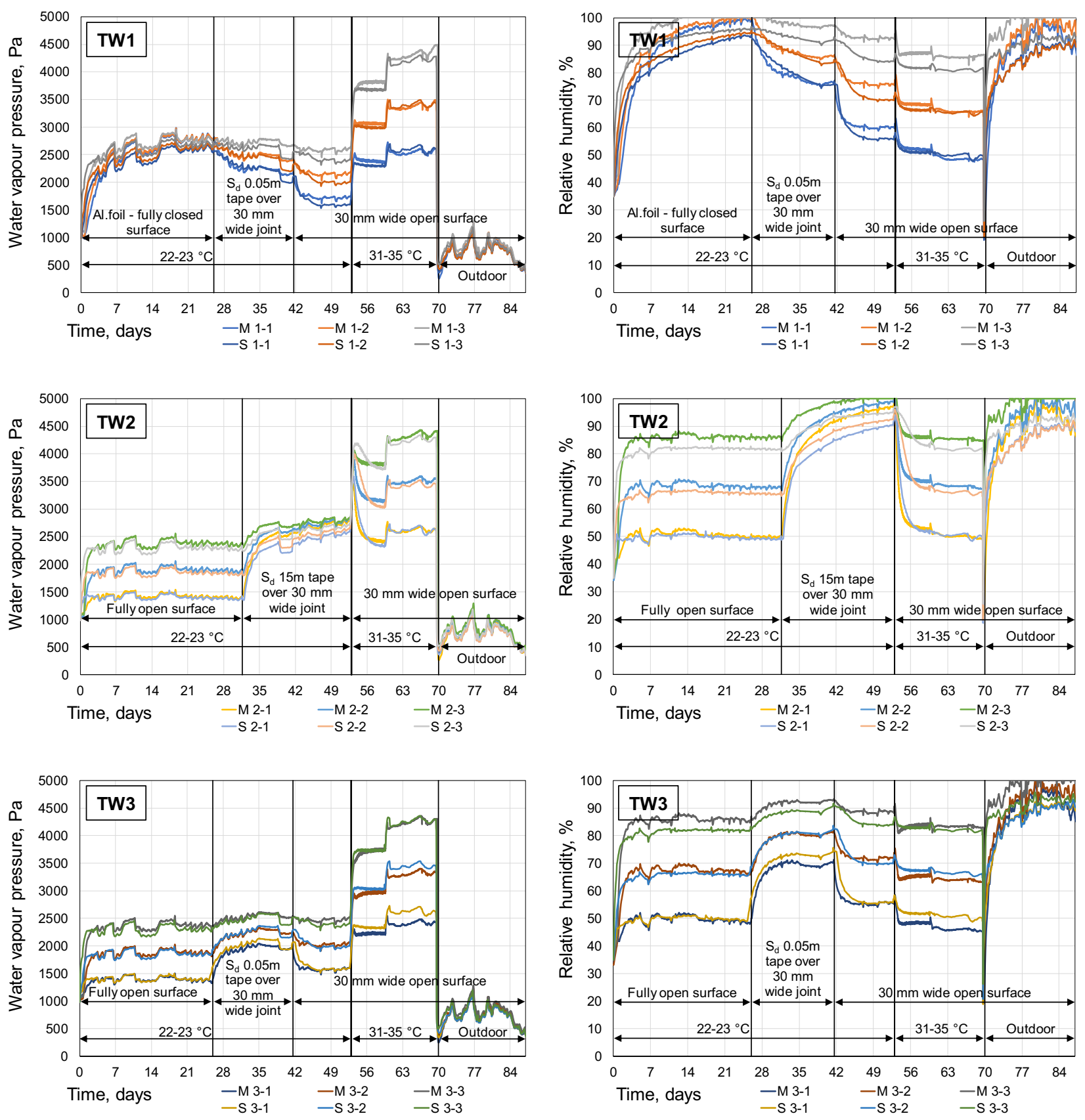

Fig. 7. Comparison of measured (M) and simulated (S) water vapour pressure (left) and relative humidity (right) on the TWs.

because there are fewer variables. If boundary conditions were fluctuating (as in the hourly climate data), the effects of the climate would not be so obvious. The graphs in Fig. 8 show the relative humidity in a $230 \mathrm{~mm} \times 3000 \mathrm{~mm}$ sandwich panel in different locations over a 365 day period of constant climate conditions, with a vapour permeable tape $\left(S_{\mathrm{d}}=0.05 \mathrm{~m}\right)$ covering the joints.

Two initial moisture contents were used:

- $\quad \mathrm{RH} 80 \%=1.5 \mathrm{~g} / \mathrm{kg}$ (according to EN 15026 standard [20]);

- $\quad$ RH $97 \%=3.5 \mathrm{~g} / \mathrm{kg}$

(limit of hygroscopic area).

The initial moisture content describes the amount of moisture inside the panel during the application of tapes (e.g. moisture due to rain that entered the panels during the installation). A moisture content of $1.5 \mathrm{~g}$ per $1 \mathrm{~kg}$ of mineral wool produces an initial RH of $80 \%$ in the panel after sealing tapes are applied over the joints.

Results show that moisture was redistributed very quickly in the panel and excessive moisture accumulated on the inner surface of the external steel sheet (Fig. 9). This happened because mineral wool is very permeable to vapour and without noteworthy moisture storage capacity.

The simulations with constant climate conditions showed that regardless of the initial moisture content high $\mathrm{RH}$ levels remained continuous on the external layers of the sandwich panels when autumn- or winter-like conditions persisted. The drying potential was very low during winter and autumn.

Some dry-out capacity existed under summer and spring climatic conditions if the external joint of the 
sandwich panel was covered with a vapour permeable tape. If summer-like conditions persisted for more than 20 days, the RH levels started to decrease near the joint in case the initial moisture content was $1.5 \mathrm{~g} / \mathrm{kg}$ (RH 80\%). However, if the initial moisture content was $3.5 \mathrm{~g} / \mathrm{kg}$ (i.e. more rain got into the panel), more than 50 days of persistent summer conditions were needed for the RH to fall below 95\% near the joint and even more time was needed to decrease the RH further inside the panel. About 240 to 260 days of persistent summer- or spring-like conditions were necessary for the farthest point from the joint to start drying. Figure 9 shows the spatial distribution of water vapour pressure and RH in the panel after 100 days of persistent hypothetical summer conditions. It is evident that the area behind the external steel sheet is experiencing near-condensing conditions if it is more than $1.5 \mathrm{~m}$ away from the diffusion open joint. However, it is unlikely that these conditions would last this long in a cold and humid climate.

It was found that the moisture dry-out capacity of such panels was very small even in best-case scenarios. Figures 10 and 11 describe the overall moisture dry-out rate from these panels per square metre of the diffusion open aperture. The standard solution with a $30 \mathrm{~mm}$ wide seam in the vertical joint would provide an aperture of $0.09 \mathrm{~m}^{2}$ per joint if the panels were $3 \mathrm{~m}$ high. This means a dry-out rate of about 0.5 to $1.5 \mathrm{~g} /$ day with initial RH $80 \%$ and 2 to $3 \mathrm{~g}$ /day at best with initial RH 97\%. The drying process through diffusion is very slow.

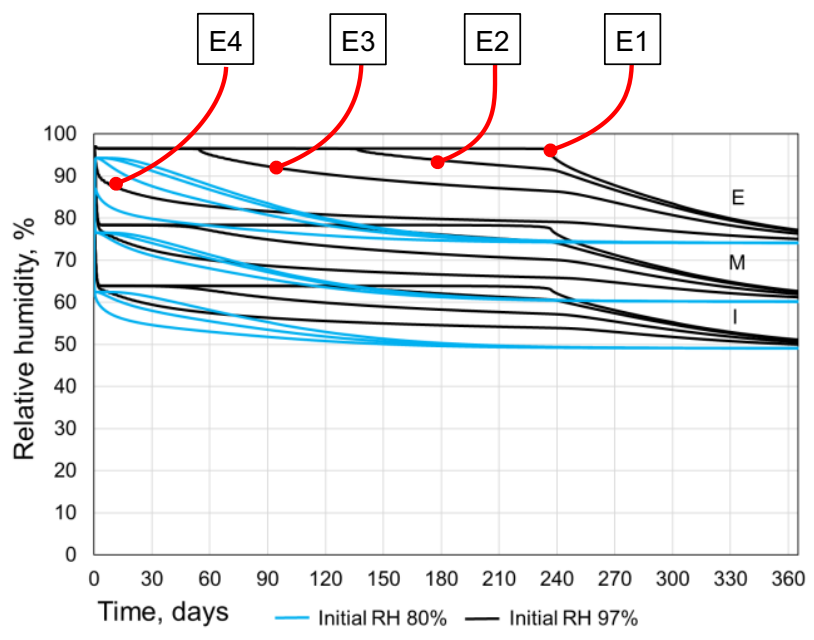

$t_{\mathrm{e}} 14.5^{\circ} \mathrm{C}, \mathrm{RH} \mathrm{H}_{\mathrm{e}} 75 \%, t_{\mathrm{i}} 20^{\circ} \mathrm{C}$ (summer)

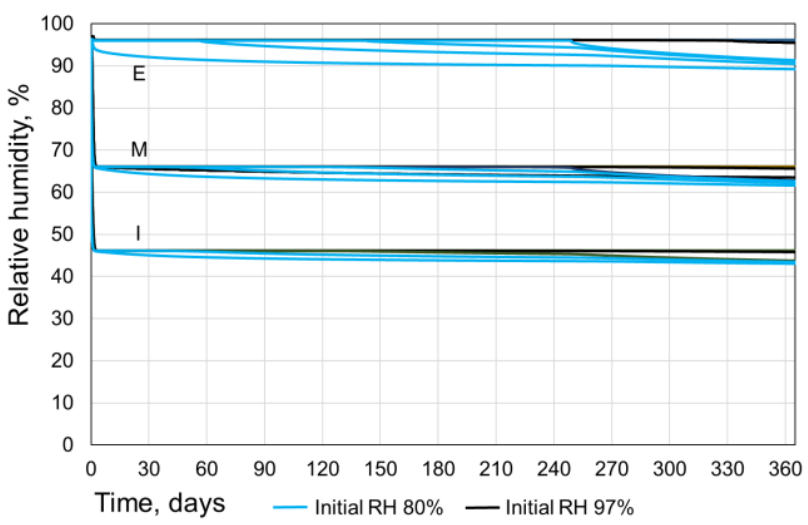

$t_{\mathrm{e}} 5.2{ }^{\circ} \mathrm{C}, \mathrm{RH}_{\mathrm{e}} 91 \%, t_{\mathrm{i}} 17^{\circ} \mathrm{C}$ (autumn)

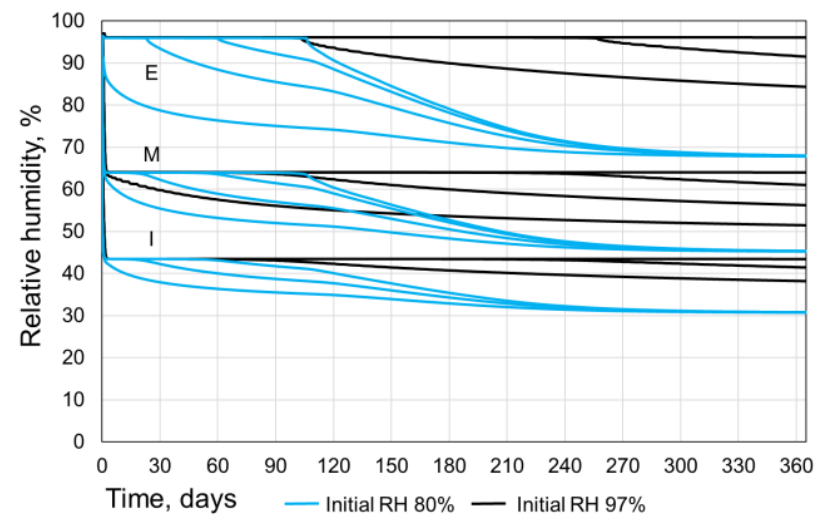

$t_{\mathrm{e}} 4.3{ }^{\circ} \mathrm{C}, \mathrm{RH}_{\mathrm{e}} 70 \%, t_{\mathrm{i}} 17^{\circ} \mathrm{C}$ (spring)

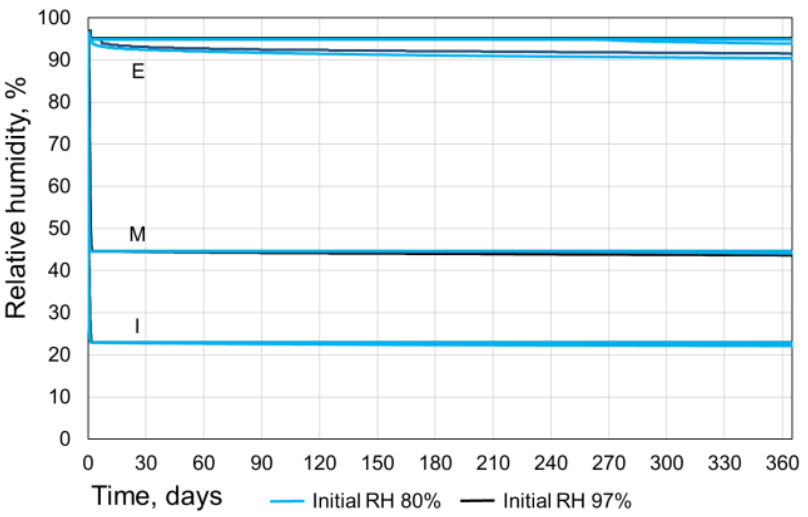

$t_{\mathrm{e}}-4.4^{\circ} \mathrm{C}, \mathrm{RH}_{\mathrm{e}} 93 \%, t_{\mathrm{i}} 17^{\circ} \mathrm{C}$ (winter)

Fig. 8. Simulated relative humidity in steel sandwich panel during 365 days of seasonal average climatic conditions with a vapour permeable tape $\left(S_{\mathrm{d}}=0.05 \mathrm{~m}\right)$ on panel external joints. $\mathrm{E}=$ behind the external steel sheet, $\mathrm{M}=$ middle of insulation, $\mathrm{I}=$ behind the internal steel sheet. The different lines represent different measurement points (e.g. E1...E4) for each location. The lines on the top left chart are referenced, but others are not for readability reasons. 


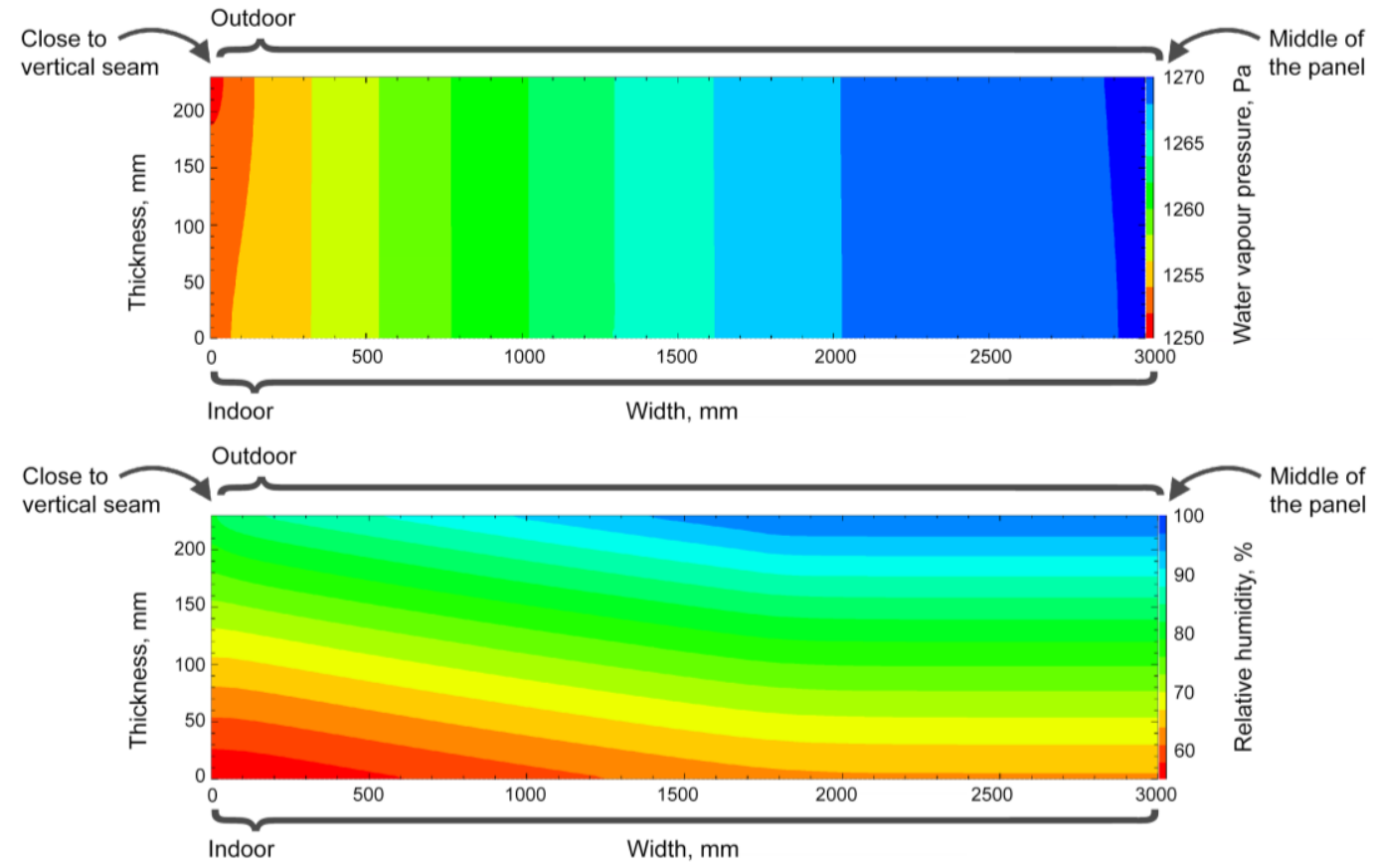

Fig. 9. Distribution of water vapour pressure (above) and RH (below) in a $0.23 \mathrm{~m} \times 3 \mathrm{~m}$ panel after 100 days of summer conditions.

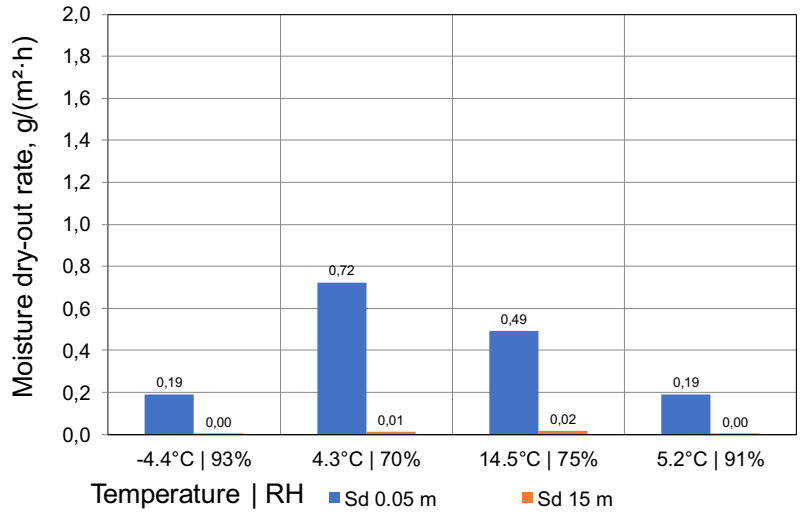

Fig. 10. Moisture dry-out rate per diffusion open aperture in different climatic conditions with initial RH $80 \%$.

\section{Discussion}

Several indoor humidity models exist [21-23]. In this study no indoor moisture loads were used because the steel faced insulated sandwich panel is assumed to be hermetic on the inner surface and the water vapour pressure is assumed to equalise with the external pressure. Therefore, the RH inside the panel depends on the temperature distribution and outdoor climate and, of course, on the initial moisture content or the amount of water that has entered the panel, for example during construction.

Excess moisture (if it exists) accumulates on the inner surface of the external steel sheet. This region has the largest hygrothermal load because of continuous wet or frost conditions. Solar driven diffusion may redistribute the excess moisture also to the inner surface of the panel.

To minimise the wetting of the panel during construction, weather protection during construction and

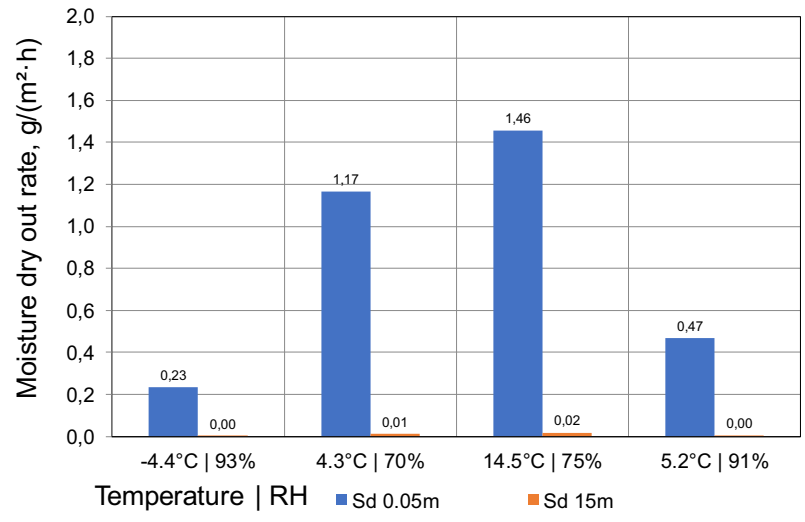

Fig. 11. Moisture dry-out rate per diffusion open aperture at different climatic conditions with initial RH 97\%.

during storage is necessary. If the panel has become wet during construction, active air convection might help to activate the drying process.

The following factors have to be taken into consideration for a deeper service life analysis:

- $\quad$ initial moisture content (load);

- water vapour permeability of joint sealing tape;

- $\quad$ distance between joints (drying out area);

- durability of panel:

- corrosion resistance of panel (depends on humidity (RH, time of wetness), temperature, time, corrosion resistance treatment (zinc and painting);

○ properties of adhesive systems, peeling;

- mould (in insulation) that could be a problem because of spores, fungal allergens, mycotoxins, microbial and volatile organic compounds;

- change of thermal and mechanical properties of insulation (mineral wool). 


\section{Conclusions}

This study analysed the moisture dry-out capacity of a steel faced insulated sandwich panel. A series of laboratory measurements were done to calibrate the hygrothermal simulation models, which were then used to analyse the moisture dry-out capacity of a typical wall assembly in different climate conditions.

The results show that panels of this type have a limited moisture dry-out capacity (about $2-3 \mathrm{~g} /$ day at best) if there is a water leakage (e.g. due to improper protection against rain during the installation of the panels). It is recommended that relatively vapour permeable seam tapes should be used in order to enable even this level of drying.

Research is scarce on the performance criteria of these panels and the extent of the problems caused by excessive moisture is unknown. Therefore, it is difficult to conclude whether the low moisture dry-out capacity is a problem or not. This study provides a starting point for future work.

This research was supported by the EC - Research Programme of the Research Fund for Coal and Steel - HAIR - Improved Durability of Steel Sandwich Panel Constructions regarding Hygrothermal and AIRtightness Performance (grant No. 754185), Estonian Centre of Excellence in Zero Energy and Resource Efficient Smart Buildings and Districts, ZEBE (grant No. 2014-2020.4.01.15-0016) funded by the European Regional Development Fund, by the Estonian Research Council (grant No. PRG483), and by European Commission through the H2020 project Finest Twins (grant No. 856602).

\section{References}

1. Z. Li, G. Q. Shen, and X. Xue, Habitat Int. 43, 240 (2014)

2. L. Jaillon, C. S. Poon, and Y. H. Chiang, Waste Manag. 29, 309 (2009)

3. C. Mao, Q. Shen, L. Shen, and L. Tang, Energy Build. 66, 165 (2013)

4. W. Lu, K. Chen, F. Xue, and W. Pan, J. Clean. Prod. 201, 236 (2018)

5. P. Pihelo, T. Kalamees, and K. Kuusk, Energy Procedia 132, 1006 (2017)

6. K. Sandberg, T. Orskaug, and A. Andersson, Energy Procedia 96, 756 (2016)

7. SAND.CORe, Best Practice Guide for Sandwich Structures in Marine Applications (FPG-50633, 2005)

8. F. Weiland, M. Kirchner, V. Rensinghoff, F. Giovannetti, O. Kastner, D. Ridder, Y. Tekinbas, and H. Hachul, J. Phys. Conf. Ser. 1343, (2019)

9. EU 305/2011, Off. J. Eur. Union 5 (2011)

10. P. Pihelo, M. Lelumees, and T. Kalamees, Energy Procedia 96, 745 (2016)

11. V. Kukk, J. Kers, and T. Kalamees, Wood Mater. Sci. Eng. 0, 1 (2019)

12. V. Kukk, A. Külaots, J. Kers, and T. Kalamees, Can. J. Civ. Eng. cjce (2019)
13. P. Pihelo and T. Kalamees, Wood Mater. Sci. Eng. 1 (2019)

14. A. J. Laukkarinen, J. Vinha, K. Kalbe, and T. Kalamees, in Nord. Symp. Build. Phys. (Tallinn, Estonia, 2020)

15. A. Nicolai, Modeling and Numerical Simulation of Salt Transport and Phase Transitions in Unsaturated Porous Building Materials, Syracuse University, (2008)

16. G. Scheffler, Validation of Hygrothermal Material Modelling under Consideration of the Hysteresis of Moisture Storage, Dresden University of Technology, (2008)

17. L. Sontag, A. Nicolai, and S. Vogelsang, Validierung Der Solverimplementierung Des Hygrothermischen Simulationsprogramms Delphin (Dresden, 2013)

18. J. Vinha, A. Laukkarinen, M. Mäkitalo, S. Nurmi, P. Huttunen, T. Pakkanen, P. Kero, E. Manelius, J. Lahdensivu, A. Köliö, K. Lähdesmäki, J. Piironen, V. Kuhno, M. Pirinen, A. Aaltonen, J. Suonketo, J. Jokisalo, O. Teriö, A. Koskenvesa, and T. Palolahti, Effects of Climate Change and Increasing of Thermal Insulation on Moisture Performance of Envelope Assemblies and Energy Consumption of Buildings (in Finnish - Ilmastonmuutoksen Ja Lämmöneristyksen Lisäyksen Vaikutukset Vaipparakenteiden Kosteusteknisessä (Tampere, 2013)

19. K. Ruosteenoja, K. Jylhä, H. Mäkelä, R. Hyvönen, P. Pirinen, and I. Lehtonen, Weather Data for Building Physics Test Reference Years in the Observed and Projected Future Climate Results from the REFI-B Project (in Finnish Rakennusfysiikan Testivuosien Sääaineistot Havaitussa Ja Arvioidussa Ilmastossa: REFI-B Hankkeen Tuloksia) (Finnish Meteorological Institute, 2013)

20. EN 15026, Hygrothermal Performance of Building Components and Building Elements Assessment of Moisture Transfer by Numerical Simulation (European Committee for Standardization, Brussels, 2007)

21. S. Ilomets, T. Kalamees, and J. Vinha, J. Build. Phys. 41, 547 (2018)

22. J. Vinha, M. Salminen, K. Salminen, T. Kalamees, J. Kurnitski, and M. Kiviste, J. Build. Phys. 42, 239 (2018)

23. S. Ilomets, T. Kalamees, and F. Tariku, Can. J. Civ. Eng. 46, 963 (2019) 